\title{
An Assessment of Spatial Distribution of Four Different Satellite-Derived Rainfall Estimations and Observed Precipitation over Bangladesh
}

\author{
Deepa Roy $^{1 *}$, S. M. Quamrul Hassan ${ }^{2}$, Syeda Sabrina Sultana ${ }^{3}$ \\ ${ }^{1}$ Department of Mathematics, Jashore University of Science and Technology, Jashore, Bangladesh \\ ${ }^{2}$ Storm Warning Center, Bangladesh Meteorological Department, Dhaka, Bangladesh \\ ${ }^{3}$ Regional Integrated Multi-Hazard Early Warning System, Dhaka, Bangladesh \\ Email: *deepa.math@just.edu.bd
}

How to cite this paper: Roy, D., Hassan, S.M.Q. and Sultana, S.S. (2020) An Assessment of Spatial Distribution of Four Different Satellite-Derived Rainfall Estimations and Observed Precipitation over Bangladesh. Journal of Agricultural Chemistry and Environment, 9, 195-205.

https://doi.org/10.4236/jacen.2020.94016

Received: August 3, 2020

Accepted: September 5, 2020

Published: September 8, 2020

Copyright $\odot 2020$ by author(s) and Scientific Research Publishing Inc. This work is licensed under the Creative Commons Attribution International License (CC BY 4.0).

http://creativecommons.org/licenses/by/4.0/

\begin{abstract}
Given that precipitation is a major component of the earth's water and energy cycles, reliable information on the monthly spatial distribution of precipitation is also crucial for climate science, climatological water-resource research studies, and for the evaluation of regional model simulations. In this paper, four satellite derived precipitation datasets: Climate Prediction Center MORPHING (CMORPH), Tropical Rainfall Measuring Mission (TRMM), the Precipitation Estimation Algorithm from Remotely-Sensed Information using an Artificial Neural Network (PERSIANN), and the global Satellite Mapping of Precipitation (GSMaP) are spatially analyzed and compared with the observed precipitation data provided by Bangladesh Meteorological Department (BMD). For this study, the different precipitations data sets are spatially analyzed from $2^{\text {nd }}$ May 2019 to $4^{\text {th }}$ May 2019 at the time of Cyclone "FANI". It is found that the satellite derived precipitation datasets are reasonably matched with the observed but slightly different.
\end{abstract}

\section{Keywords \\ CMORPH, TRMM, PERSIANN, GSMaP, FANI}

\section{Open Access}

\section{Introduction}

Bangladesh is a country situated in the north-eastern part of South Asia within $88.01^{\circ} \mathrm{N}-92.41^{\circ} \mathrm{E}$ and $20.57^{\circ} \mathrm{N}-26.64^{\circ} \mathrm{N}$. The area is about $147,610 \mathrm{sq}$. km. The land of Bangladesh is very flat: Elevation is about $1-37 \mathrm{~m}$ above sea level except for small portions in the southeast (elevation about $200 \mathrm{~m}$ ) which is bordered with Myanmar and in the northeast (elevation about $100 \mathrm{~m}$ ) which is bordered 
with Shilling hill of India. Due to this geographical position, Bangladesh experiences the highest amount of rainfall among the SAARC region. Accurate and consistent rainfall observations are very important for various climatological studies to support agricultural and water management development. The economic development of this country largely depends on agriculture. The frequent occurrence of tropical cyclones causes severe loss to the country's economy and lives and properties of its inhabitants. From the "Dhaka Tribune", a national English-language broadsheet daily newspaper published in Dhaka, Bangladesh, reported that the cyclone "FANI" flooded 63,000 hectares of land and destroyed crops on 1800 hectares. The agriculture department suffered damages worth Tk38 crore. The forestry sector suffered damages worth Tk5 crore, while the amount was Tk2.84 crore for fisheries. Therefore accurate and timely measurement of precipitation is very crucial especially during the time of tropical cyclones.

Satellite-derived precipitation products are considered important for estimating precipitation amounts for various climatological studies and most importantly in the field of agriculture. Currently, there are several quasi-global high resolution satellite precipitation products including near-real-time (3B42RT, daily derived from 3B42RT) of TRMM, CMORPH algorithm, PERSIANN and GSMaP. Because such products have global (or quasi-global) orientation, the performances of satellite precipitation products are expected to vary from place to place. It is thus necessary to evaluate the performances of satellite precipitation products with local rain gauge data before these products can be used with high confidence in a specific study area. Such evaluation and inter-comparison can also help to identify the most accurate and appropriate satellite precipitation product among various alternatives. Numerous researches have been taken place to compare and examine the quality of different satellite derived rainfall products, such as Climate Prediction Center MORPHING (CMORPH), Tropical Rainfall Measuring Mission (TRMM), the Precipitation Estimation Algorithm from Remotely-Sensed Information using an Artificial Neural Network (PERSIANN), the global Satellite Mapping of Precipitation (GSMaP), in various regions of the world [1]-[6]. Zifeng [7] evaluated the abilities of 3B42, CMORPH, and GMS5-TBB data in reflecting the gauge rainfall for Typhoon "Bilis" (2006) and found that three retrieved rainfall datasets could reflect the rainfall patterns well and show considerable skill in the light and moderate rainfall categories, but not for heavy rainfall. Estimation of maximum rainfall potential using TRMM derived multisatellite rain rate data appeared to be useful to provide good guidance to the forecaster for forecasting of 24 hours rainfall amount expected from a landfalling cyclone like "Aila" [8]. Chang [9], analyzed TRMM 3B42 rainfall estimates for ten typhoons that made landfall over Taiwan during 2007-2010 and it is found by comparing with radar reflectivity maps that the overall rain band structures within the Tropical Cyclones are revealed by the TRMM data quite well when the Tropical Cyclones are both over ocean and land [9].

However, it is still unclear as to which precipitation product is "best" over dif- 
ferent regions because of disagreement among satellite observations. For example, Nesbitt [4] found that the CMORPH and PERSIANN estimate higher rainfall rates relative to TRMM in the Sierra Madre Occidental (i.e. the western Mexico mountain range running approximately north-south) whereas Dinku [10] found that the TRMM and CMORPH performance is better in Ethiopia and Zimbabwe. In contrast, de Goncalves [1] found PERSIANN performance is better than TRMM in South America. For this, satellite derived precipitation products need to be validated and deeply analyzed to improve the accuracy and timely prediction of rainfall as they can differ due to geographical location, topography, and climate [11] [12]. Such evaluation and inter-comparison can also help to identify the most accurate and appropriate satellite precipitation product among various alternatives. It is thus necessary to evaluate the performances of satellite precipitation products with local rain gauge data before these products can be used with high confidence in a specific study area.

\section{Synoptic Condition of Extremely Severe Cyclonic Storm "FANI"}

Extremely severe cyclonic storm "FANI" was first originated from a low pressure area formed over the east Equatorial Indian Ocean (EIO) and adjoining southeast Bay of Bengal (BoB) in the early morning of $25^{\text {th }}$ April. Under favorable environmental conditions, it concentrated into a Depression (D) over the same region on the morning of $26^{\text {th }}$ April. Moving nearly northwestwards, it intensified into a deep depression (DD) over the same region in the early morning and further into a cyclonic storm (CS) "FANI" around noon on $27^{\text {th }}$ April over southeast $\mathrm{BoB}$ and adjoining east EIO. It temporarily intensified during the evening of $2^{\text {nd }}$ May to early hours of $3^{\text {rd }}$ May reaching the peak intensity of 115 knots (wind speed). Thereafter from $3^{\text {rd }}$ early morning, it weakened slightly. Then it weakened into a CS in the early morning of $4^{\text {th }}$ May over western parts of Gangetic West Bengal and lay centered about $60 \mathrm{~km}$ northwest of Kolkata.

\section{Study Region and Data Sets}

\subsection{Study Region}

The study was conducted over Bangladesh setting the latitude $18^{\circ} \mathrm{N}-28^{\circ} \mathrm{N}$ and longitude $84^{\circ} \mathrm{E}-96^{\circ} \mathrm{E}$.

\subsection{Data Sets}

\subsubsection{Rain Gauge Data}

Daily rainfall data from $2^{\text {nd }}$ May 2019 to $4^{\text {th }}$ May 2019 at different stations in Bangladesh are collected from the Storm Warning Centre (SWC) of Bangladesh Meteorological Department (BMD).

\subsubsection{CMORPH}

CMORPH (Climate Prediction Center MORPHING technique) produces global 
precipitation analyses at very high spatial and temporal resolution. It was developed at the NOAA (National Oceanic and Atmospheric Administration) Climate Prediction Center (CPC). This technique uses precipitation estimates that have been derived from low orbiter satellite microwave observations exclusively, and whose features are transported via spatial propagation information that is obtained entirely from geostationary satellite IR data. This method is highly flexible as it allows the incorporation of any rainfall estimate from PM satellites. The CMORPH V1.0 product has been available as three-hour data since $1^{\text {st }}$ January 1998 , at a $0.25^{\circ} \times 0.25^{\circ}$ spatial resolution, and with a $60^{\circ} \mathrm{N}-60^{\circ} \mathrm{S}$ overall coverage.

\subsubsection{TRMM}

The TRMM (Tropical Rainfall Measuring Mission) instrument was launched on 27 November 1997 as a joint effort by NASA (National Aeronautics and Space Administration) and the Japanese Space Agency [13] [14]. TRMM provides precipitation data from December 1997 to the present (available from http://TRMM.gsfc.nasa.gov). This product was obtained from the TRMM MultiSatellite precipitation analysis (TMPA) algorithm which combines Infrared (IR) and Passive Microwave (PM) data retrievals [15] [16]. The TMPA products provide precipitation for the spatial coverage of $50^{\circ} \mathrm{N}-50^{\circ} \mathrm{S}$ at the $0.25^{\circ} \times 0.25^{\circ}$ latitude-longitude resolution. The TRMM 3B42RT product is one type of the TEMPA products, and it is calibrated and merged with monthly rain gauge data. The temporal resolution of TRMM 3B42 is 3-hourly, thus allowing us to obtain daily precipitation for evaluation.

\subsubsection{PERSIANN}

The PERSIANN (the Precipitation Estimation Algorithm from Remotely-Sensed Information using an Artificial Neural Network) [17] [18] [19] Climate Data Record (PERSIANN-CDR) was developed by scientists at the Center for Hydrometeorology and Remote Sensing, University of California, Irvine [20]. The input data for the PERSIANN CDR algorithm comes from: 1) Gridded Satellite Data (GridSat-B1) from the International Satellite Cloud Climatology Project (ISCCP) B1 Infrared Window (IRWIN) Channel, and 2) Global Precipitation Climatology Project (GPCP) v2.2.

\subsubsection{GSMaP}

The GSMaP (the global Satellite Mapping of Precipitation) was established by the Japan Science and Technology Agency (JST) in 2002 to produce global precipitation products with high resolution and high precision [21].

\section{Methodology}

The four satellite derived rainfall products CMORPH, TRMM, PERSIANN, and GSMaP form $1^{\text {st }}$ May 2019 to $4^{\text {th }}$ May 2019 were spatially analyzed along with observed rainfall data. Station wise rainfall amounts of rain gauges were then compared with the four different satellite estimate rainfall amounts. For spatial 
distribution, the four satellite derived rainfall products are analyzed using GrADS (Grid Analysis and Display System) version: 2.2.1.

\section{Results and Discussion}

The spatial distribution of observed rainfall on $2^{\text {nd }}, 3^{\text {rd, }}$ and $4^{\text {th }}$ May 2019 is
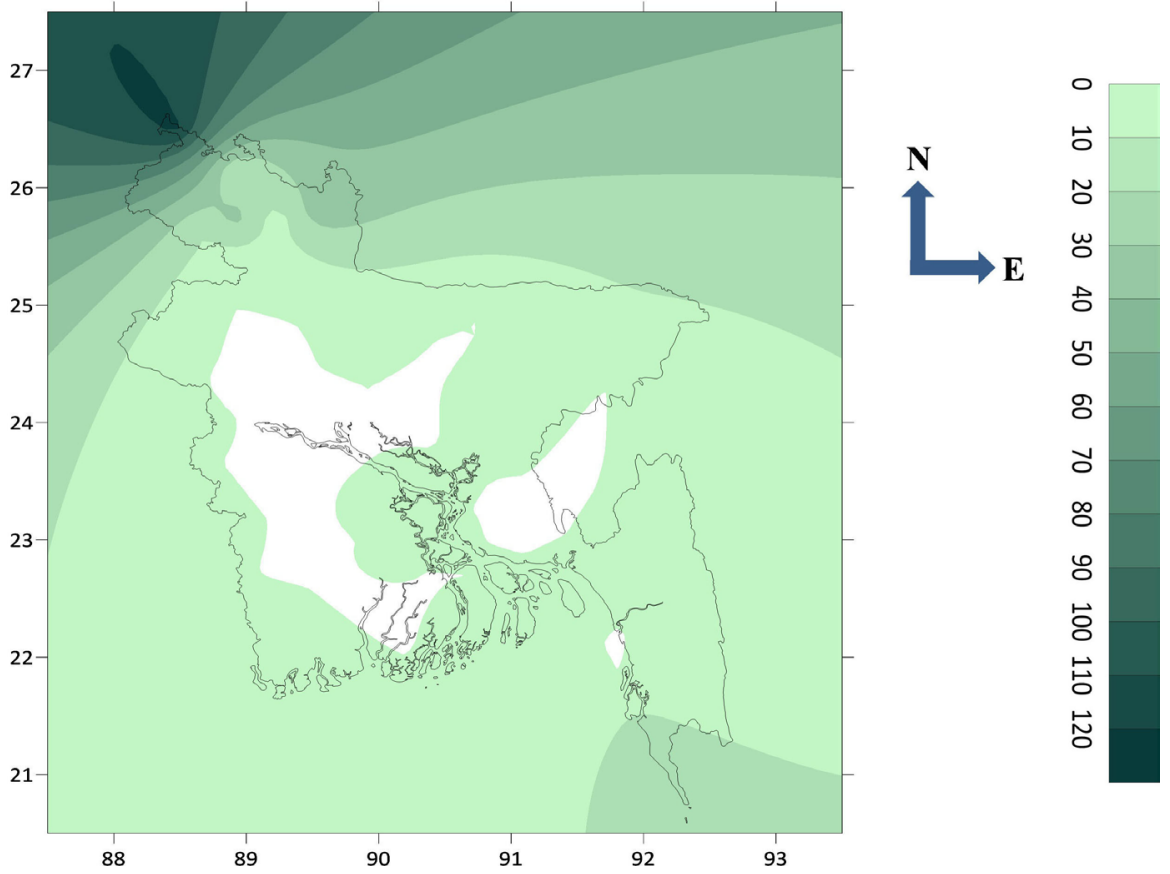

Figure 1. Spatial distribution of observed rainfall (mm) on 02 May 2019.

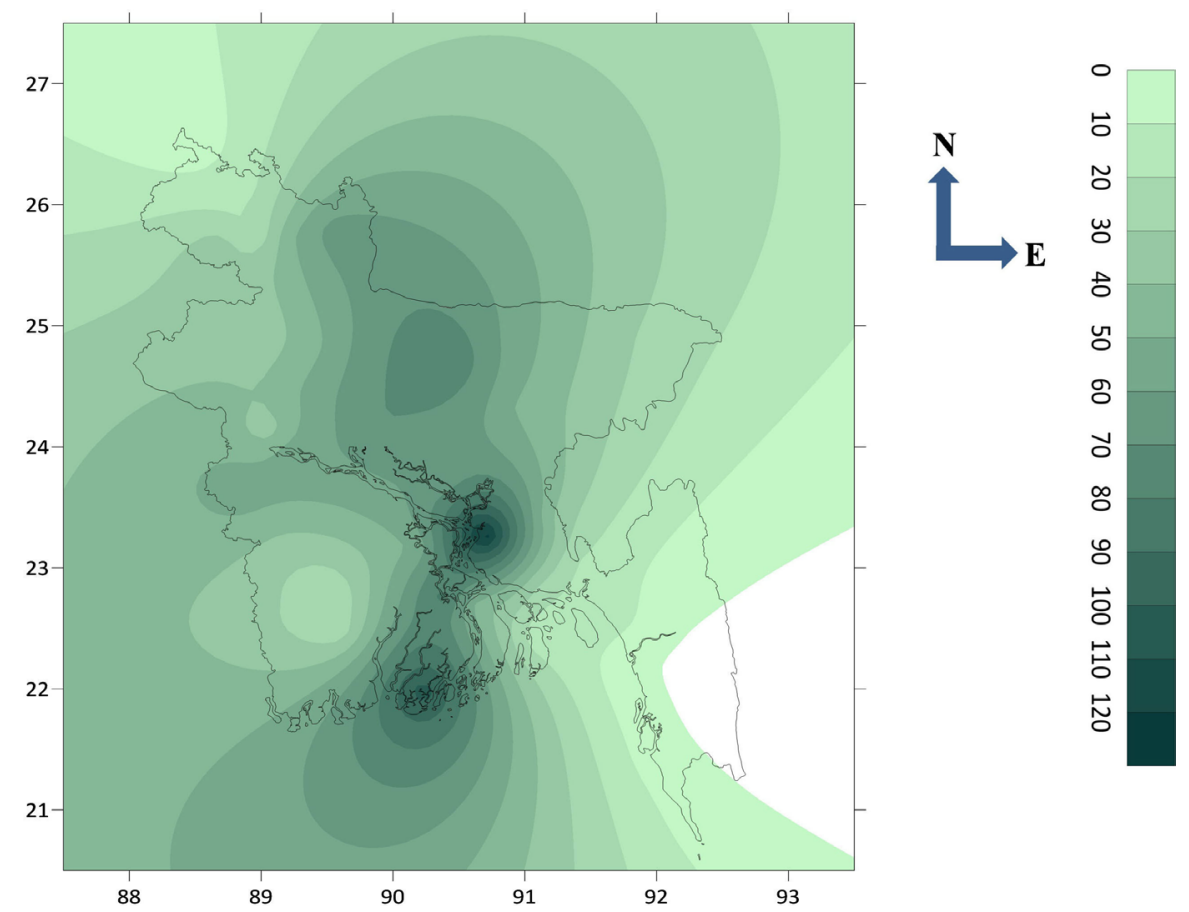

Figure 2. Spatial distribution of observed rainfall (mm) on 03 May 2019. 

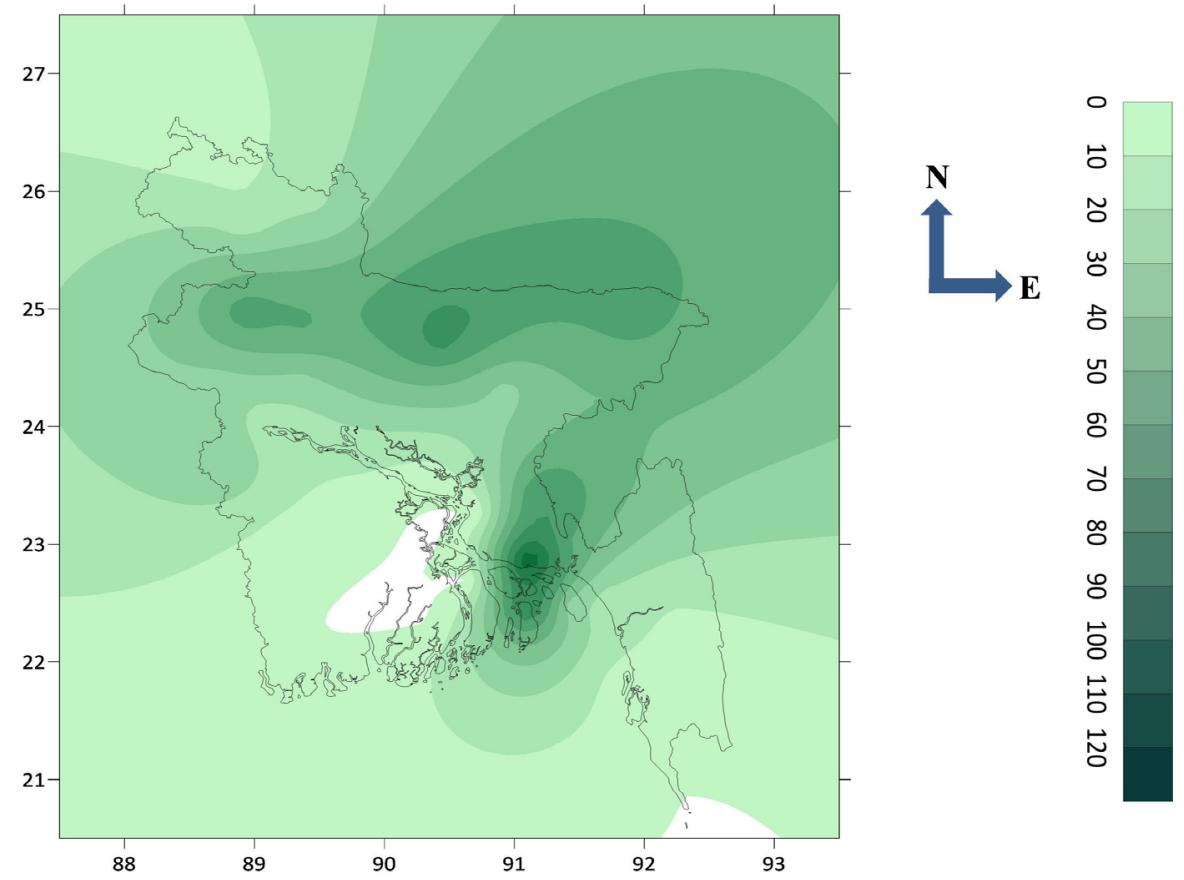

Figure 3. Spatial distribution of observed rainfall (mm) on 04 May 2019.

shown in Figures 1-3 respectively. From Figure 1, it can be observed that there is no significant rainfall on $2^{\text {nd }}$ May and the northwestern part of Bangladesh received very low amount of rainfall. On $3^{\text {rd }}$ May the rainfall amount significantly raised and the south part of the country experienced a high amount of precipitation (Figure 2). Again from Figure 3, we can see that the rainfall decreased all over the country except some southeastern parts that experienced low amount of precipitation.

Figure 4(a)-(d) shows the satellite derived rainfall on $2^{\text {nd }}$ May for CMORPH, TRMM, PERSIANN and GSMaP respectively. All rainfall products estimated the same amount of precipitation and significantly showed no rainfall all over the country which agreed with the observed rainfall.

Figure 5(a)-(d) shows the satellite derived rainfall on $3^{\text {rd }}$ May for CMORPH, TRMM, PERSIANN and GSMaP respectively. It can be seen that among all the satellite derived rainfall products, TRMM was very close to the observed precipitation. GSMaP did not show any significant rainfall on that day although there was rainfall on the southern parts of the country. On the other hand, CMORPH showed a significant amount of rainfall but not very close to the observed rainfall distribution (Figure 2). In the case of PERSIANN rainfall estimation product, it showed very little amount in some places on that very day.

Figure 6(a)-(d) shows the satellite derived rainfall on $4^{\text {th }}$ May for CMORPH, TRMM, PERSIANN and GSMaP respectively. From the figure, it can be seen that the TRMM showed a little amount of precipitation in some parts of the country which agreed with the observed spatial distribution while PERSIANN product was overestimated in some regions. Both CMORPH and GSMaP showed reasonably well match with the observed precipitation distribution. 


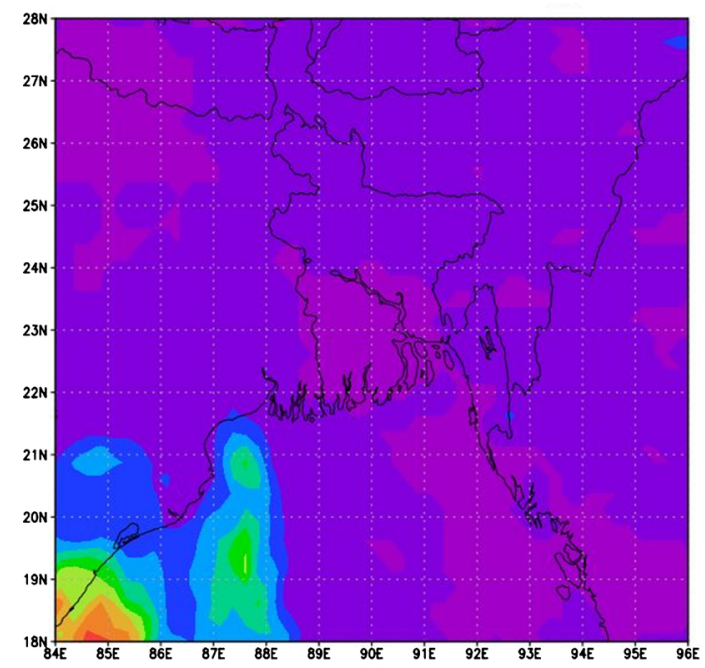

(a)

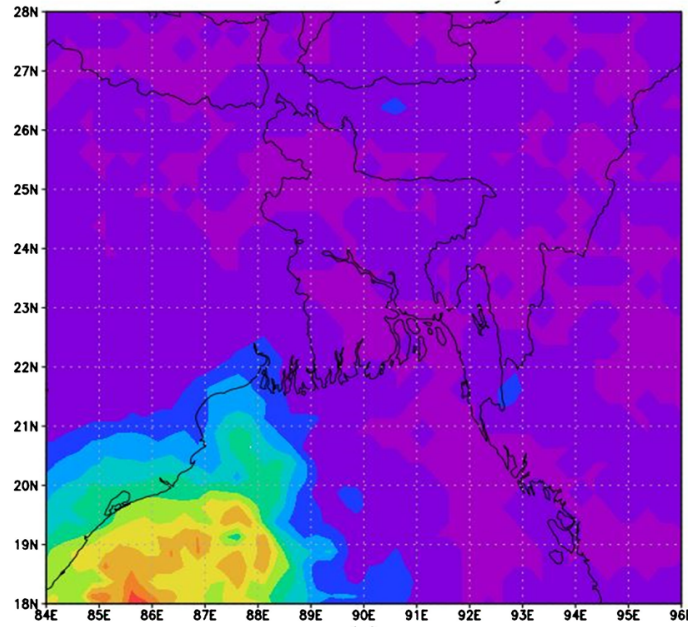

(c)

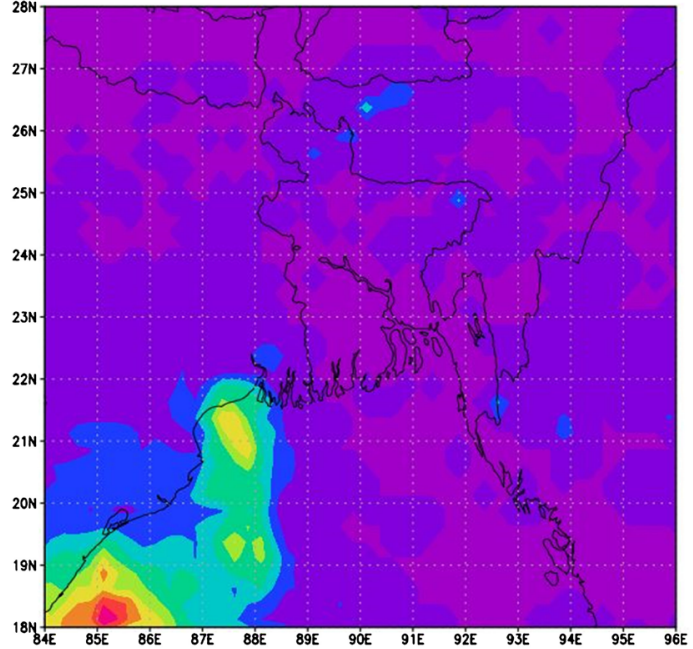

(b)

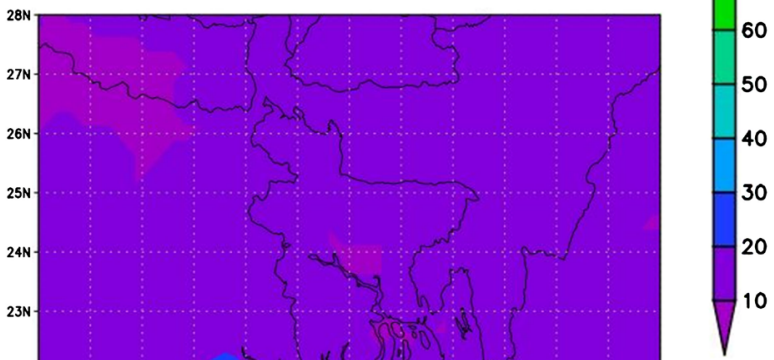

(d)

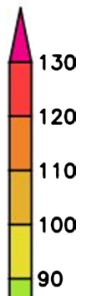

80

50

40

30

20

10

Figure 4. Spatial distribution of four satellite derived rainfall (mm): (a) CMORPH (b) TRMM (c) PERSIANN (d) GSMaP on 02 May 2019.

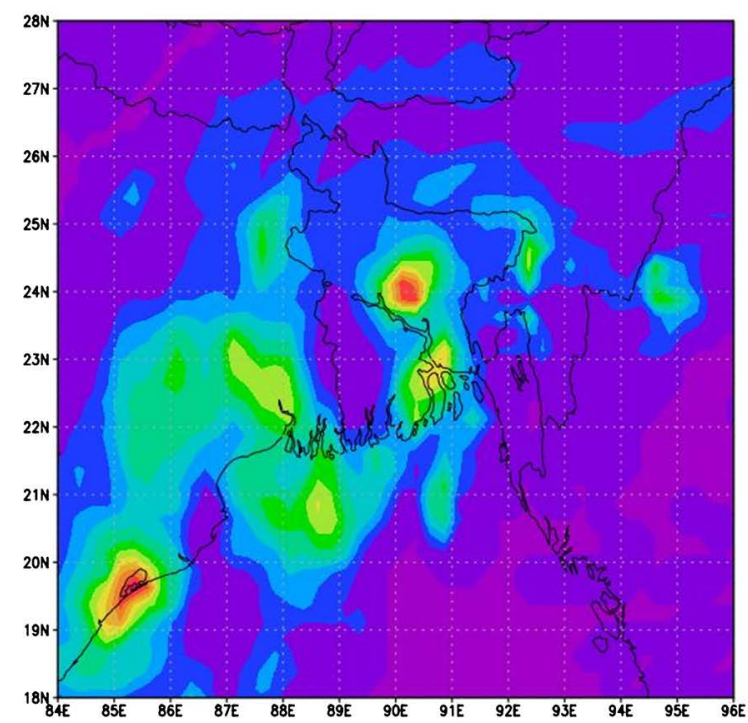

(a)

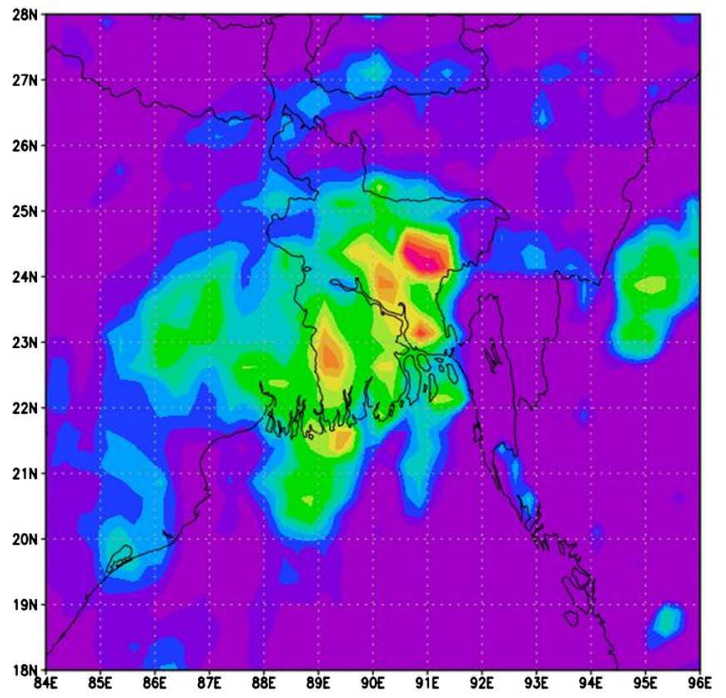

(b) 


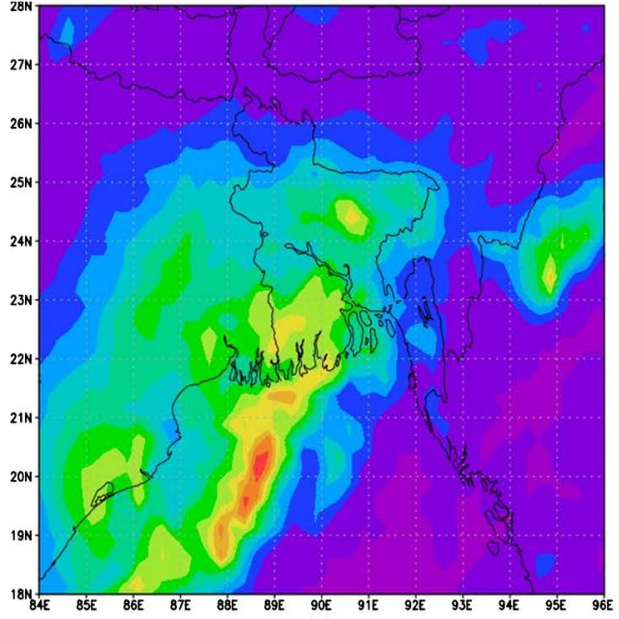

(c)

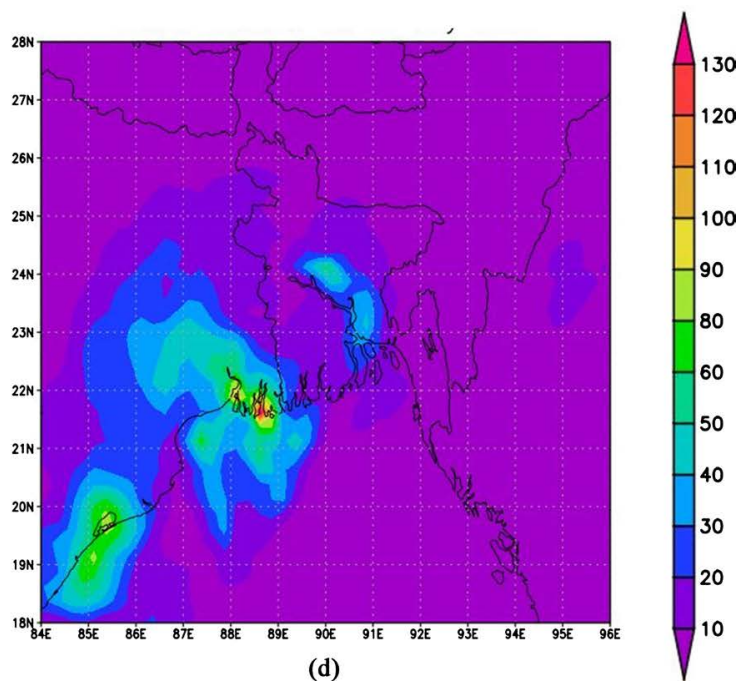

Figure 5. Spatial distribution of four satellite derived rainfall: (a) CMORPH (b) TRMM (c) PERSIANN (d) GSMaP on 03 May 2019.
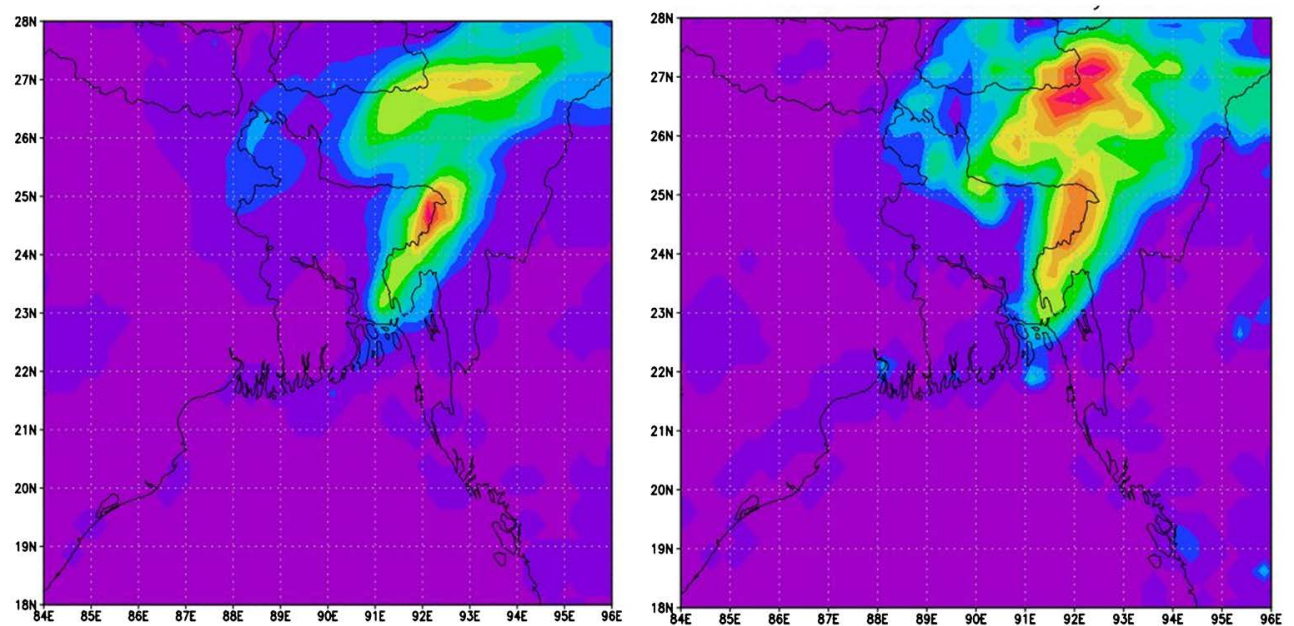

(a)

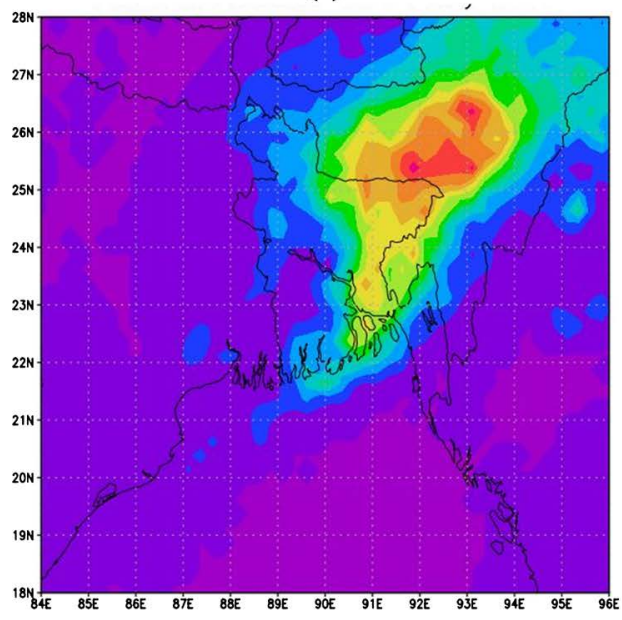

(b)

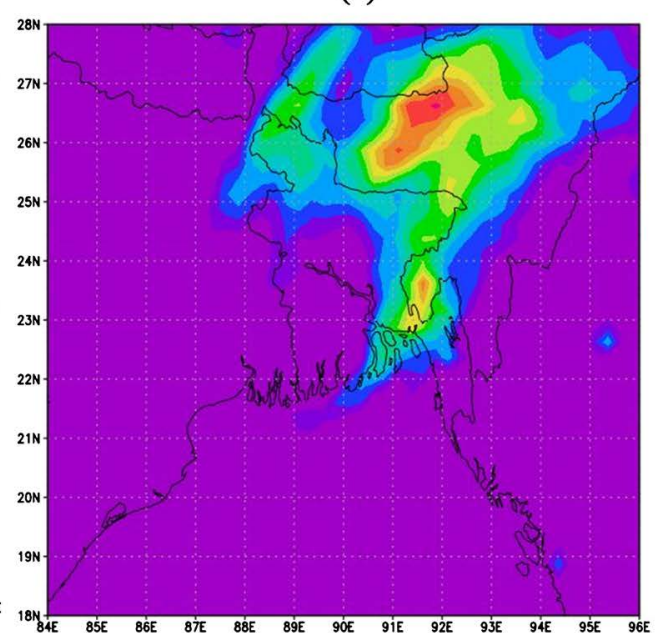

(d)

Figure 6. Spatial distribution of four satellite derived rainfall: (a) CMORPH (b) TRMM (c) PERSIANN (d) GSMaP on 04 May 2019. 


\section{Conclusion}

Different satellite derived rainfall products have been evaluated globally and in some cases regionally. But there are significant differences in their performances and this is due to the geographical location, climate, and rainfall regime. In some cases, these products completely agreed with the observed precipitation while in other cases they significantly varied. Among the four satellite derived rainfall products, 3B42RT TRMM exhibited the best performance compared with CMORPH, PERSIANN and GSMaP. CMORPH showed quite good performance in rainfall estimation where PERSIANN exhibited the poorest performance. Satellite derived rainfall could be a good source of rainfall estimation where observation facilities are not available but they need to be validated more deeply. Further study is needed for the evaluation of other satellite derived rainfall products for accurate rainfall estimation and timely prediction.

\section{Acknowledgements}

The authors would like to acknowledge the GSMaP Project sponsored by JST-CREST, NOAA Climate Prediction Center (CPC) for CMORPH and PERSIANN data, and NASA for the TRMM 3B42RT data used in this study. The authors are very grateful to the Bangladesh Meteorological Department (BMD) for the observed data and technical support.

\section{Conflicts of Interest}

The authors declare no conflicts of interest regarding the publication of this paper.

\section{References}

[1] de Goncalves, L.G.G., Shuttleworth, W.J., Nijssen, B., Burke, E.J., Marengo, J.A., Chou, S.C., Houser, P. and Toll, D.L. (2006) Evaluation of Model-Derived and Remotely Sensed Precipitation Products for Continental South America. Journal of Geophysical Research, 111, D16113. https://doi.org/10.1029/2005JD006276

[2] Dai, A., Lin, X. and Hsu, K.L. (2007) The Frequency, Intensity, and Diurnal Cycle of Precipitation in Surface and Satellite Observations over Low- and Mid-Latitudes. Climate Dynamics, 29, 727-744. https://doi.org/10.1007/s00382-007-0260-y

[3] Asadullah, A., McIntyre, N. and Kigobe, M. (2008) Evaluation of Five Satellite Products for Estimation of Rainfall over Uganda. Hydrological Sciences, 53, 1137-1150. https://doi.org/10.1623/hysj.53.6.1137

[4] Nesbitt, S.W., Gochis, D.J. and Lang, T.J. (2008) The Diurnal Cycle of Clouds and Precipitation along the Sierra Madre Occidental Observed during NAME-2004: Implications for Warm Season Precipitation Estimation in Complex Terrain. Journal of Hydrometeorology, 9, 728-743. https://doi.org/10.1175/2008JHM939.1

[5] Zhou, T., Yu, R., Chen, H., Dai, A. and Pan, Y. (2008) Summer Precipitation Frequency, Intensity, and Diurnal Cycle over China: A Comparison of Satellite Data with Rain Gauge Observations. Journal of Climate, 21, 3997-4010. https://doi.org/10.1175/2008JCLI2028.1

[6] Stisen, S. and Sandholt, I. (2009) Evaluation of Remote-Sensing-Based Rainfall 
Products through Predictive Capability in Hydrological Runoff Modelling, Hydrological Processes, 24, 879-891. https://doi.org/10.1002/hyp.7529

[7] Zifeng, Y., et al. (2009) Verification of Tropical Cyclone-Related Satellite Precipitation Estimates in Mainland China. Journal of Applied Meteorology and Climatology, 48, 2227-2241. https://doi.org/10.1175/2009JAMC2143.1

[8] Biswas, H.R. (2013) A Case Study for Cyclone “Aila” for Forecasting Rainfall Using Satellite Derived Rain Rate Data. Mausam, 64, 77-82.

[9] Chang, L.T.C., Cheung, K.K.W. and McAneney, J. (2013) Case Study of TRMM Satellite Rainfall Estimation for Landfalling Tropical Cyclones: Issues and Challenges. Tropical Cyclone Research and Review, 2, 109-123.

[10] Dinku, T., Chidzambwa, S., Ceccato, P., Connor, S.J. and Ropelewski, C.F. (2008) Validation of High-Resolution Satellite Rainfall Products over Complex Terrain. International Journal of Remote Sensing, 29, 4097-4110. https://doi.org/10.1080/01431160701772526

[11] Meng, J., Li, L., Hao, Z.C., Wang, J.H. and Shao, Q.X. (2014) Suitability of TRMM Satellite Rainfall in Driving a Distributed Hydrological Model in the Source Region of Yellow River. Journal of Hydrology, 509, 320-332. https://doi.org/10.1016/j.jhydrol.2013.11.049

[12] Xue, X., Hong, Y., Limaye, A.S., Gourley, J.J., Huffman, G.J., Khan, S.I. and Chen, S. (2013) Statistical and Hydrological Evaluation of TRMM-Based Multi-Satellite Precipitation Analysis over the Wangchu Basin of Bhutan: Are the Latest Satellite Precipitation Products 3B43V7 Ready for Use in Ungauged Basin? Journal of Hydrology, 499, 91-99. https://doi.org/10.1016/j.jhydrol.2013.06.042

[13] Kummerow, C., Barnes, W., Koju, T., Shiue, J. and Simpson, J. (1998) The Tropical Rainfall Measuring Mission (TRMM) Sensor Package, Journal of Atmospheric and Oceanic Technology, 15, 809-817. https://doi.org/10.1175/1520-0426(1998)015\%3C0809:TTRMMT\%3E2.0.CO;2

[14] Gao, H., Wood, E.F., Jackson, T.J., Drusch, M. and Bindlish, R. (2006) Using TRMM/TMI to Retrieve Surface Soil Moisture over the Southern United States from 1998 to 2002. Journal of Hydrometeorology, 7, 23-38.

https://doi.org/10.1175/JHM473.1

[15] Guo, R. and Liu, Y. (2014) Evaluation of Satellite Precipitation Products with Rain Gauge Data at Different Scales: Implications for Hydrological Applications. Water, 8, 281. https://doi.org/10.3390/w8070281

[16] Huffman, G., Bolvin, D., Nelkin, E., Wolff, D., Adler, R., Gu, G. and Stocker, E. (2007) The TRMM Multisatellite Precipitation Analysis (TMPA): Quasi-Global Multiyear, Combined-Sensor Precipitation Estimates at Fine Scales. Journal of Hydrometeorology, 8, 38-55. https://doi.org/10.1175/JHM560.1

[17] Hsu, K.-L., Gao, X., Sorooshian, S. and Gupta, H.V. (1997) Precipitation Estimation from Remotely Sensed Information Using Artificial Neural Networks. Journal of Applied Meteorology, 36, 1176-1190. https://doi.org/10.1175/1520-0450(1997)036\%3C1176:PEFRSI\%3E2.0.CO;2

[18] Novella, N. and Thiaw, W. (2010) Validation of Satellite-Derived Rainfall Products over the Sahel. 1-9, Camp Springs, Wyle Information Systems/CPC/NOAA, MD.

[19] Novella, N.S. and Thiaw, W.M. (2013) African Rainfall Climatology Version 2 for Famine Early Warning Systems. Journal of Applied Meteorology and Climatology, 52, 588-606. https://doi.org/10.1175/JAMC-D-11-0238.1

[20] Ashouri, H., Hsu, K.-L., Sorooshian, S., Braithwaite, D.K., Knapp, K.R., Cecil, L.D., Nelson, B.R. and Prat, O.P. (2015) PERSIANN-CDR: Daily Precipitation Climate 
Data Record from Multisatellite Observations for Hydrological and Climate Studies. Bulletin of the American Meteorological Society, 96, 69-83. https://doi.org/10.1175/BAMS-D-13-00068.1

[21] Ushio, T., Sasashige, K., Kubota, T., Shige, S., Okamoto, K., Aonashi, K., Inoue, T., Takahashi, N., Iguchi, T., Kachi, M., Oki, R., Morimoto, T. and Kawasaki, Z.-I. (2009) A Kalman Filter Approach to the Global Satellite Mapping of Precipitation (GSMaP) from Combined Passive Microwave and Infrared Radiometric Data. Journal of the Meteorological Society of Japan, 87A, 137-151. 